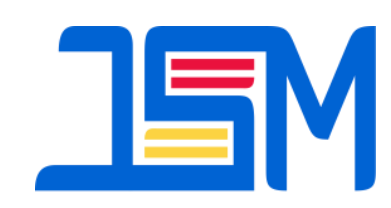

JAMBURA SCIENCE OF MANAGEMENT

Jambura Science Of Management

Homepage : http://ejurnal.ung.ac.id/index.php/jsm

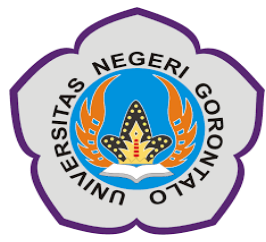

\title{
Analysis of Differences in Share Performance between SOEs and Non- SOEs Based on Short-Term Underpricing and Long-Term Underperformance
}

\author{
Novriska Mointi ${ }^{1}$, Yayu Isyana Pongoliu ${ }^{2}$ \\ ${ }^{1}$ Department of Management, Economic Faculty, Gorontalo State University \\ ${ }^{2}$ Economic Faculty, Gorontalo State University \\ E-mail: novriska_s1manajemen2015@mahasiswa.ung.ac.id
}

\begin{abstract}
:
This study aims to determine the differences in the performance of shares of SOEs and NonSOEs companies that conduct IPOs on the Indonesia Stock Exchange in the period 20102014 based on short-term underpricing and long-term underperformance. Sampling is done by using purposive sampling technique. Data analysis techniques used the independent sample parametric test and the non-parametric difference test mann whitney u test. The results showed that there were no differences in the performance of shares of SOE and NonSOE companies conducting IPOs on the Indonesia Stock Exchange in the 2010-2014 period based on short-term underpricing. This means that in the short term investments in shares of Non-BUMN companies are more profitable for investors and are detrimental to the company because the funds obtained are less. But in testing based on long-term underperformance, the results of the study showed that there were differences in the performance of the shares of SOE and Non-SOE companies conducting IPOs on the IDX for the 2010-2014 period. This shows that BUMN companies have better performance than Non-BUMN companies, because government ownership gives more value and can operate in various sectors.
\end{abstract}

Keywords: Stock Performance, BUMN Companies, Non BUMN Companies, Undepricing, Underperformance

Underpricing is an interesting phenomenon because it is experienced by most Indonesian capital markets. Because of that, often in the primary market (IPO) there is an underpricing phenomenon
(Ritter, 1991; P. Kumar 2012; Aggrawal et al, 1993). The level of underpricing of BUMN and Non BUMN companies can be seen in the following graph. 


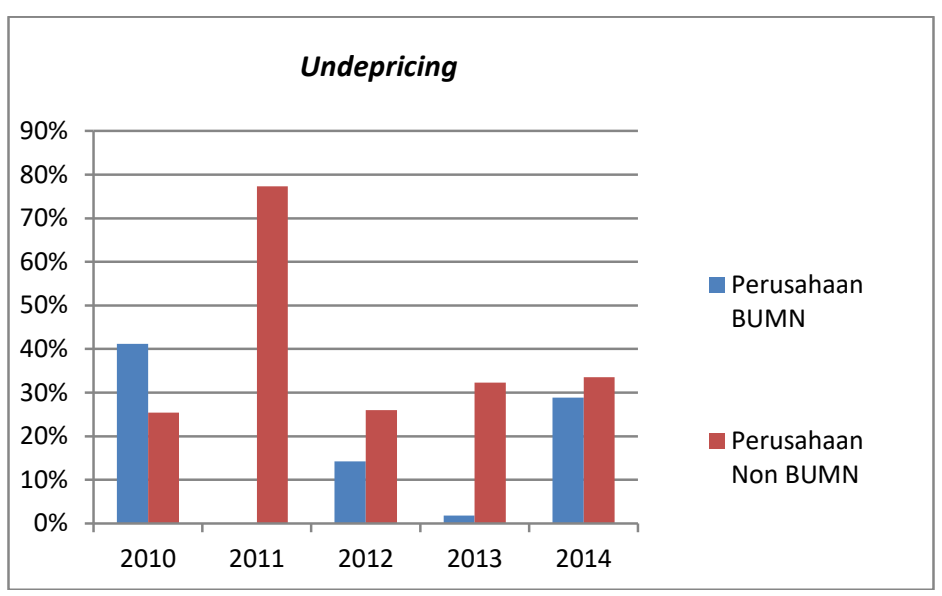

Source: yahoofinance.com and data processed

\section{Gambar 1. Underpricing}

The graph above shows that nonBUMN companies have a higher level of underpricing compared to the level of underpricing in BUMN companies. BUMN companies did not experience underpricing in 2011 while non-BUMN companies experienced higher underpricing by $77 \%$. The cause of underpricing is due to asymmetric information between issuers, underwriters and investors (Baron, 1982 in Karsana,
2009). Another phenomenon, which may occur besides underpricing in the short term, is a decline in performance (underperformed) on long-term performance. The phenomenon of underpcing and underperformance may also occur in shares of companies in Indonesia that are registered in the Indonesian capital market such as BUMN and Non BUMN companies.

\section{Table 1 Underperformance}

\begin{tabular}{|l|c|}
\hline \multicolumn{1}{|c|}{ Information level of } & $\%$ \\
\hline $\begin{array}{l}\text { The } \\
\text { underperformance of BUMN } \\
\text { companies }\end{array}$ & $0.65 \%$ \\
\hline $\begin{array}{l}\text { Underperformance level of } \\
\text { Non-BUMN companies }\end{array}$ & $0.10 \%$ \\
\hline
\end{tabular}

Source: yahoofinance.com and data processed

The table above shows that NonBUMN companies are underperforming more than BUMNs. This means that BUMN companies have better performance than Non-BUMN companies. The cause of stock performance underperformance after the IPO is because most companies do have poor performance, risk measurement errors (Guntoro et al, 2008; Florentina, 2014; Ritter, 1991) and too optimistic attitudes shown by investors (Beatty, 1989). 
Some of the results of the study there are differences in the short-term and long-term returns so that researchers do testing again. This research is reviewed from the structure of company ownership, namely BUMN and Non BUMN after IPO. This study examines SOE and Non SOE companies that conduct IPO in the short term experience the phenomenon of undepricing and in the long term experience a decline in performance (underperformance) for 3 (three) years. Thus, this study aims to obtain empirical evidence whether there are significant differences between the phenomenon of short-term underpricing and long-term undeperformance periods used, namely 2010-2014.

\section{METHOD}

This type of research used in this research is quantitative research with secondary data analysis. Quantitative research is research that emphasizes testing research variables with numbers and conducting data analysis with statistical procedures (Sugiono, 2012). The population in this study were all SOE and Non SOE companies conducting IPOs on the Indonesia Stock Exchange which consisted of 125 companies with a sample of 60 companies consisting of $4 \mathrm{SOE}$ companies and 56 Non-SOE companies that met the criteria. The data in this study use data in the form of stock price data and IHSG data. Daily stock price data for each sample company and IHSG price data are obtained from the yahoofinance.com database and for IPO stock prices obtained from e-bursa.com.

\section{RESULT AND DISCUSSION}

\section{Is there a difference in the phenomenon of short-term underpricing that occurs in SOE and Non-SOE companies conducting IPOs for the period 2010- 2014?}

Based on the analysis of the data obtained, that in the short term there is no difference in the phenomenon of underpricing that occurs in SOE and Non SOE companies conducting IPOs for the period 2010-2014. This can be seen from the results of the mann-whitney $u$ test shows that (H_a1) is rejected because the Asymp Sig (2-tailed) value of 0.662 is greater than the $\operatorname{sig} \alpha$ of 0.05 . The results of this study are in line with research by Pujiharjanto and C.ambar (2013) which states that in the short term there is no difference in the underpricing phenomenon that occurs in SOEs and Non-SOEs companies conducting IPOs.

Judging from the results of the calculation of the average initial return of non-SOE companies, $28 \%$ were more underpricing than SOEs, namely $21 \%$. This means that Non-BUMN companies do not obtain maximum funding from the IPO. But rationally a low pricing strategy or with the phenomenon of underpricing can attract investors to buy their shares. Problems in determining the price of shares in the primary market are also due to different goals desired by the issuer and 
underwriter. The issuer wants a high share price while the underwriter wants a lower share price, as a precaution if many shares are unsold and to maintain the underwriter's reputation.

The undepricing phenomenon occurs due to an imbalance of information between the issuer and the underwriter which will affect the initial offering stock price. Issuers lack information about the market, so issuers must accept the price given by the underwriter for the offering of shares. So that at the time of the IPO the issuer did earnings management so as not to be detected by the market. The level of earnings management when IPOs in NonBUMN companies are made higher, so that it becomes one of the important sources of information used by investors in assessing stock prices. So that some managers of Non-SOE companies try to make their company's financial statements look good with a view to influencing stock performance in the short term.

For non-BUMN companies the phenomenon of underpricing is considered as an adverse condition because the ability to obtain maximum funds cannot be achieved. Even so, the cheap price of shares in the primary market compared to prices in the secondary market is also profitable for Non-BUMN companies because a company that experiences underpricing means that the company will benefit investors. So that when a Non-SOE company shares again, it is likely that the shares will be sold.

The underpricing phenomenon that occurs in the short term can also benefit investors. Many investors choose to accelerate the velocity of their money so they choose short-term investments because they provide faster returns and investors have the opportunity to get profits (capital gains). This research is supported by Whidawati and Panjaitan (2013) who conducted research on BUMN and BUMS companies in the Indonesia Stock Exchange regarding the phenomenon of underpricing. In the short term, investors will benefit when investing in shares of Non-SOE companies, so that the goal to increase the capital of NonSOEs companies and to increase company publications in the future can be achieved, although it is more risky to invest in shares of Non-SOEs companies. In the future, investors will get more profit if they buy shares of Non-BUMN companies in the primary market. The findings in this study indicate that to invest in shares, investors do not need to show whether the investment is in shares of BUMN or Non BUMN companies. In terms of BUMN share ownership it is owned by the State but this does not mean that it is better than Non BUMN shares whose shares are owned by private companies. Thus the phenomenon of underpricing has important implications in determining funding policies for companies and investment policies for investors.
Is there a difference in the phenomenon of long-term underperformance that occurs in SOEs and Non-SOEs companies that conduct IPOs for the period 2010-2014? 
Based on the analysis of the data obtained, that in the long run there is a significant difference in the phenomenon of underperformance that occurs in SOEs and Non-SOEs companies that conduct IPOs for the period 2010-2014. This can be seen from the independent sample $t$ test results that $\left(\mathrm{H} \_\mathrm{a} 2\right)$ are accepted because the Asymp Sig (2-tailed) value of 0.006 is smaller than the sig $\alpha$ of 0.05 . The results of this study are consistent with the research of Indah and Kartika (2004). The results of his research show that in the long run there are significantly differences in the phenomenon of underperformance that occurs in state-owned and non-SOE companies conducting IPOs.

The performance of non-BUMN companies has decreased (undeperformance), which means that BUMN companies have better performance. The phenomenon of underperformance occurs because companies and underwriters create a surplus of initial demand through the primary market by making a lower bid price (underpricing), then in the long run the market will correct the price. Shares offered at an IPO are high-risk objects, so in this condition there is high uncertainty. Investors who are optimistic will buy IPO shares at high prices, whereas pessimistic investors will buy IPO shares at low prices.

\section{CONCLUSSION}

Investors who buy shares at the time of the IPO will get a fairly high initial return due to the large demand for these shares at the beginning of the trading period in the secondary market. So that stocks that get the highest initial return will produce low yields in the long run. For this reason, in the long run, investment in BUMN shares can minimize the risk of losses that arise. Investors tend to choose long-term investments in SOE shares capable of producing greater profits that can be re-invested and able to produce profits again. So that the return obtained is greater for income every period.

In the long run, it is more profitable for investors to invest in shares of BUMN companies, because BUMN shares have a relatively old age, can operate in various sectors that are regulated by the government and the largest capital owner (51\%) is the State. Government ownership gives more value and raises the stigma that BUMN companies are not easily bankrupt because they have strong defenses. This research is supported by Tampubulon et al (2002) in the long term investment in SOE shares gives a greater return and the risk of investing in SOE shares is smaller than the risk of investing in shares of Non SOE companies. According to Widhawati and Panjaitan (2013) investment in BUMN shares have a high security net compared to shares of Non-BUMN companies.

Based on the results of the study, the following conclusions can be drawn: 
1. The results of the analysis using the mann-whitney u test method, it was found that in the short term there were no differences in the phenomenon of underpricing that occurred in BUMN and non BUMN companies in the period 2010-2014. This shows that in the short term the undepricing phenomenon occurs due to an imbalance of information between the issuer and the underwriter which will affect the initial offering price. Issuers manage earnings so they are not detected by the market. The level of earnings management when IPOs in non-BUMN companies are made higher, so that it becomes one of the important sources of information used by investors in assessing stock prices. So that in the short term investors choose investment in non-BUMN companies.

2. The results of the analysis using the independent sample test method, it was found that in the long run there are differences in the phenomenon of underperformance that occurs in stateowned and non-state companies in the period 2010-2014. Judging from the calculation of the relative wealth of non-BUMN companies are experiencing underperformance compared to SOE companies. This shows that BUMN companies have better performance than non-BUMN companies. Investors choose a longterm investment in BUMN shares because the return obtained is greater to obtain income every period. In the long term investment in shares of BUMN companies is more profitable for investors, because the shares owned by the government can operate in various sectors, giving rise to the stigma that BUMN companies can provide more value and not easy to go bankrupt.

\section{SUGGESTION}

Based on the conclusions above, suggestions can be given as follows:

1. The company should carefully choose the underwriter so that in determining the IPO stock price so that it does not experience a high enough underpricing. Before offering public shares, the company should be able to show a really good financial performance and have adequate information about the capital market, so that the initial price agreement of shares formed between the company and the underwriter does not harm both parties.

2. In the short term, investors should buy and invest in shares of Non-BUMN companies, because Non-BUMN companies have a higher level of underpricing. However, for long-term investment, investors should choose SOE companies, because SOE companies have better performance compared to Non-SOE companies. 


\section{REFERENCESS}

Aditya, Alvin. 2017. Perbedaan Kinerja Saham Perusahaan Keuangan Dan Non Keuangan Berdasarkan ShortTerm Underpricing Dan LongTerm Underperformance. Skripsi.

Alteza, Muniya. 2009. Underpricing Emisi Saham Perdana: Suatu Tinjauan Kritis.Jurnal Manajemen, Vol. 9 No.2.

Aggarwal, R., et al. 1993. The Aftermarket Performance of Initial Public Offerings in Latin America. Financial Management. Vol. 22: hal 42-53.

Beatty, Randolph P. 1989. Auditor Reputation and the Pricing of Initial Public Offering. Accounting Review

Brealey, Myers dan Markus. 2006. DasarDasar Manajemen Keuangan Perusahaan. Erlangga. Jakarta.

Brau, J. C., dan Fawcett, S. E. (2006). Initial Public Offerings: An Analysis of Theory and Practice. The Journal of Finance, 61(1), 399436.

Duque, J. dan Almeida, M. 2000. Ownership Structure And Initial Public Offering In Small Economies - The Case Of Portugal. Paper for the ABN-AMBRO International Conference on Initial Public Offerings.

Florentina, Martha Nita. 2014. Karakteristik Penawaran Umum Saham Perdana: Kinerja Saham Jangka Pendek dan Kinerja Saham
Jangka Panjang pada Pasar Modal Indonesia. E-Journal Graduate Unpar. Vol.1, No.2. Magister Management; Universitas Katolik Parahyangan.

Fatiha, Galih dan Isynurwardhana Deannes. 2012. Analisis Kinerja Saham Setelah Initial Publik Offering pada Perusahaan yang Terdaftar di BEI Periode 2006-2009. Skripsi. Universitas Telkom

Freidlan, J M. 1994. Accounting Choice Of Issuers Of Initial Public Offerings. Contemporary Accounting Research.

Guntoro, Adhi dan Harahap, Tatiek N. 2008. Analisis Perbedaan Kinerja Saham Jangka Penderk dan Jangka Panjang pada Perusahaan IPO di Pasar Modal Indonesia. Jurnal Riset Bisnis Indonesia.

Hartono, Jogiyanto. 2010. Teori Portofolio Dan Analisis Investasi. Yogyakarta: Edisi 7. BPFE.

Handayani, Sri Retno. 2008. Analisis Faktor-Faktor yang Mempengaruhi Underpricing pada Penawaran Umum Perdana (Studi Kasus pada Perusahaan Keuangan yang Go Publik di Bursa Efek Jakarta Tahun 2000-2006). Universitas Diponegoro, Semarang.

Indriarti Kentis MG dan Kartika Andim. 2004. Analisis Perbedaan Kinerja Saham Jangka Pendek Dan Jangka Panjang Pada Perusahaan Yang Melakukan IPO Di Pasar Modal Indonesia. Jurnal Bisnis dan Ekonomi Vol.11 No. 1 
Irawan, Puji. 2015. Pengaruh struktur kepemilikan, corporate governance, dan underwriter reputation terhadap IPO underpricing. Skripsi. Universitas Diponerogo.

Islam, Malik, dan Uddin Riaz . 2011. Long Run Price Performance Of IPO Stocks In Bangladesh. Journal Of Finance and Banking.

Jogiyanto. 2010. Studi Peristiwa: Menguji Reaksi Pasar Modal Akibat Suatu Peristiwa.Yogyakarta: BPFEYogyakarta.

Karsana, Yusef Widya. 2009. Analisis Kinerja Saham Emiten Dalam Periode Satu Tahun Setelah Penawaran Perdana. Media Riset, Auditing \& Informasi.

Kusumawati, Denata. 2017. Analisis Kinerja Saham Dalam Jangka Pendek Dan Jangka Panjang Setelah Initial Public Offering (Ipo) Di Bursa Efek Indonesia Tahun 20062016. Skripsi.

Maria, Eva. 2011. Analisis Kinerja Saham Jangka Panjang Perusahaan yang Melakukan Initial Public Offering di Bursa Efek Jakarta. ISSN 141286676 Vol. 10 No. 20. Lembaga Penelitian dan Pengabdian Masyarakat, Universitas Singaperbangsa, Karawang.

Nopriyandi, Fajar. 2016. Valuasi Harga Saham Dengan Metode Free Cash Flow To Equity Dan Price Earning Ratio (PER) studi kasus PT Semen Baturaja Tbk. Tesis. Universitas Lampung Bandar Lampung.
Nurcahyo, Didik Indra. 2014. Pengaruh Struktur Kepemilikan Saham dan Ukuran Perusahaan Terhadap Kinerja Perusahaan yang Terdaftar di BEI tahun 2010-2013. Skripsi.

Ong, Edianto. 2008. Technical Analysis for Mega Profit. Edisi Pertama. Jakarta: Mega Publishing.

P.Kumar, Venkata Vijay. 2012. A study of undepricing of Initial Public Offers (IPO) and its impact on Performance of IPO stocks in Indian Financial Markets. IMM Indore.

Paulia, Saint, Armanu Thoyib, M.Syafiie Idrus. 2010. Analisis Reaksi Pasar Modal Setelah Pengumuman IPO pada Perusahaan yang Terdaftar di BEI. WACANA. Vol. 13 No. 3. Universitas Brawijaya.

Prastiwi dan Kusuma. 2001. Analisis Kinerja Surat Berharga Setelah Penawaran Perdana (IPO) di Indonesia. Jurnal Ekonomi dan Bisnis Indonesia.

Pujiharjanto, C.Ambar. 2013. Fenomena Underpricing Kinerja Jangka Panjang dan Overreaction Pada perusahaan BUMN dan NON BUMN yang Melakukan IPO Pada Tahaun 1991-2013. Seminar Nasional SMART membaca jaman dalam prespektif menajemen.

Retnowati, E. 2013. Penyebab Underpricing Pada Penawaran Saham Perdana di Indonesia. Jurnal Dinamika Akuntansi.

Ritter, J. R. 1991. The Long-Run Performance Of Initial Public Offerings. Journal of Finance. 
Sahoo, Seshadev dan Rajib Prabina. 2010. After Market Pricing Performance of Initial Public Offerings (IPOs) : Indian IPO Market 2002-2006. Vikalpa.

Shiller, R.J. (1990). Speculative Prices and Popular Models. Journal of Economic Perspectives, Vol. 4:2.

Sugiono. 2012. Metode Penelitian Kuantitatif, Kualitatif, dan $R \& D$. Alfabeta, Bandung.

Sugiyono. 2017. Metode Penelitian Kuantitatif, Kualitatif, dan $R \& D$. Alfabeta. Bandung.

Tampubolon, Supriyono dan Gomulya, 2002. Kinerja Return Jangka Panjang Investasi Saham BUMN dan Non BUMN pada Pasar Perdana di BEJ. Digital Library.

Tandelilin, Eduardus. 2010. Portofolio dan Investasi Teori dan Aplikasi. Kanisius. Yogyakarta.

Widhawati, L.Yunia Panjaitan, 2013. Analisis perbedaan fenomena shortterm underpricing dan long-term underperformance. Jurnal manajemen.

Yosephine, B. 2010. Pengaruh Financial Leverage, Return On Equity (ROE), Ukuran Perusahaan Terhadap Tingkat Underpricing Pada Perusahaan Yang Melakukan IPO. Skipsi. Universitas Sumatera Utara.

Yuliati, Ika. 2016. Analisis reaksi pasar modal terhadap kinerja sahamsaham perusahaan setelah pengumuman IPO yang terdaftar di BEI periode 2005-2014. Skripsi. Universitas Lampung, Bandar Lampung.

https://finance.yahoo.com/quote/ge/history / Diakses Sabtu, 9 Februari 2019.

https://gopublic.idx.co.id/2016/06/22/manf aat-go-public/ Diakses Selasa, 19 Maret 2019.

https://www.ojk.go.id/. Diakses Jumat, 1 Februari 2019.

https://www.sahamok.com/emiten/ipo/

Diakses Minggu, 26 Januari 2019. 